REFLECTIONS:

NEUROLOGY AND

THE HUMANITIES

Section Editor

Anne W. McCammon,

MD, FAAN

\title{
Doctors without weapons
}

\section{"You people are pathetic"}

Jack E. Riggs, MD, CAPT, MC, USN (Ret)

Correspondence to Dr. Riggs: jriggs@wvu.edu
"How can you come to a war and not bring a weapon? Every soldier must have a weapon. That's the rule!" My boss was emphatic. "You people are pathetic."

Of course, he was right. Here we were, nearly 400 sailors in the Kuwait desert with only 50 M16 rifles and 50 9-mm pistols. Based on a Cold War scenario, our field hospital would only be responsible for internal security; we would depend upon surrounding units for external security. Although located at a resort compared to Iraq or Afghanistan, we were now responsible for our own personal security. No one was allowed outside a military camp without a weapon. Even with only 100 weapons, I was always in compliance with that directive as I moved my sailors around between the combat support hospital and 10 troop medical clinics.

After about a month of effort, I was able to obtain 100 additional weapons from a Navy depot in Crane, Indiana. Although many were not functional, the Army had a small weapons refurbishing unit at Camp Doha that restored them to "functioning-like-new" condition.

My boss was not impressed. My unit was still nearly 200 weapons short. I sent him a memo acknowledging that although I was not in compliance with the rule, none of my sailors traveled outside of camp without a personal weapon. In frustration, I told him that I could not bring my unit into compliance, and that he should report this up the chain of command.

That is exactly what he did. The 2-star general forwarded my boss' complaint and my memo up to the 3-star level. Quite frankly, I knew no one was going to give my medical unit 200 more unnecessary weapons. Sure enough, 1 week later, a 3 -star general and admiral gave my unit an exemption from the one man (or woman) one weapon rule.

If I thought my days of being harassed over weapons were over, I was wrong. Another rule reared its ugly head: every service member carrying a weapon had to be qualified on that weapon within the previous 6 months. Since we were going to be in Kuwait for almost a year, that rule meant that everyone would have to requalify. I was in deeper trouble than my boss realized. When we left the States, we had not actually qualified on our weapons. We had only performed familiarization firing. I knew that half of my sailors could not likely hit the broad side of a barn at 10 paces if their lives depended upon it. My boss was correct: we were pathetic.

I sent 25 of my sailors to requalify at the Udairi training range at Camp Buehring. Only 2 sailors qualified. My boss had me over a barrel, and he knew it. I could ask for, and likely get, another exemption. No one was going to shut down medical operations; that would cost lives. I had personally qualified on numerous occasions with both the rifle and pistol with Marine and Seabee units and felt strongly that all personnel who carried a weapon should be comfortable and confident that they could use it safely. Acknowledging that my sailors could not effectively defend themselves would not only be an embarrassment, but also an admission of leadership failure.

I told my boss that I would not fight him on this requalifying issue. However, I also told him that my sailors could not qualify using the Army's procedure. He was willing to give me some latitude as long as I was willing to assure him that at 6 months into our rotation every sailor carrying a weapon would be qualified on that weapon.

My command master chief (the unit's senior enlisted sailor) was a gunner's mate and a range master who had won several national shooting contests. When I informed him of the agreement that I had reached with my boss, his response was classic.

"Skipper, when are you going to stop writing checks that I might not be able to cash for you?"

"What's the big deal?" I replied, laughing. "Surely, you can find me a range somewhere in this whole country of Kuwait that we can take over. We have 8 civilian police officers in our unit and you are a certified range master. Surely, you guys are good enough to train and coach this pathetic bunch of docs."

Within 48 hours, the unit's senior enlisted personnel had identified a rifle and pistol range at the Kuwait

Listen to Dr. Riggs read this story, available on the iPad ${ }^{\circledR}$ and Android ${ }^{\mathrm{TM}}$ devices.

Any assertions and opinions, explicit or implicit, are those of the author and should not be construed to represent those of the United States Navy, Army, or Air Force. 
Naval Base, just 20 minutes from Camp Arifjan. Those ranges, however, were a safety nightmare. Metal target posts and light poles, as well as flat cement blocks running the length of each shooting lane, were ricochet hazards that would all have to be removed. The Kuwaiti naval officer running these ranges told me we were welcome to upgrade the ranges and shoot there as long as we did all the work, provided all the materials, and allowed Kuwaiti forces to use the range any time they wanted. I eagerly accepted those terms.

Master chief sternly lectured me about my poor negotiating skills. However, within 48 hours, he and my senior enlisted petty officers secured promises from US Army and Air Force support units in Kuwait to provide the heavy equipment and materials required to refurbish these ranges. I then realized that we were not the only support unit in Kuwait that did not want to use the Udairi range for requalification. As long as those other support units could use the ranges, they were willing to provide us the materials — as long as we did all the work.

I sent regular updates to my boss and the first general in my chain of command. I kept expecting a stand-down order but none came. In fact, my boss insisted that the Army put up signs (figure) at the ranges designating me as the range officer-incharge. From his perspective, those signs ensured that if something bad happened, I would be the one responsible and accountable. However, I took the signs as clear evidence that the US Army had authorized a Navy medical unit to operate a pistol and rifle range. The only instruction that I received from the general was that no rounds were to be fired until the Army's range safety officer had certified the ranges. I took that instruction as a green light to proceed full steam ahead.

There was one other complication: ammunition. I could not practically comply with the Army's procedure for obtaining and returning live training ammunition and run a 24/7 medical operation, so I told my boss that I would get my own ammunition. After yet another lecture, master chief and the senior enlisted sailors solved that problem. Combat units returning from Iraq had to count and turn in all their live ammunition. Since our hospital and troop medical clinics had their own armories, we volunteered to take all loose M16 and $9 \mathrm{~mm}$ bullets off their hands. The majority of units were only too happy to save themselves the chore of counting loose rounds and just officially turn in unopened cases of ammunition. We soon had so much ammunition that we supplied all the training ammunition to other support units using our ranges.

The civilian police officers in our unit did a magnificent job of providing the necessary one-on-one instruction to successfully qualify each of our sailors on their weapon. Weapons qualification turned into a huge morale booster for my sailors. Instead of spending a full day at the Udairi range, 10-12 sailors

\section{Figure The author next to a sign signifying him (a medical officer) as the officer-in-charge of a pistol range in Kuwait in 2005}

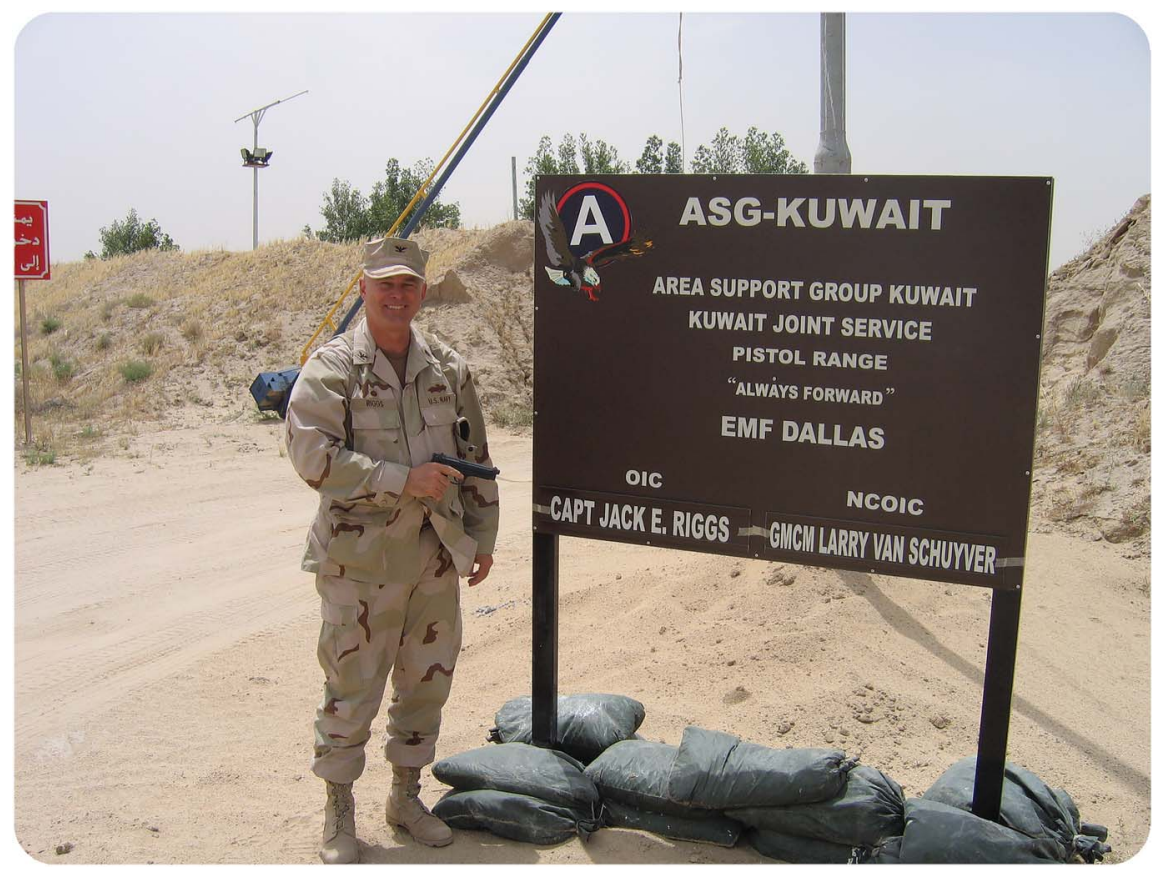

The weapon in this photograph is in the "safe" condition; magazine out, no round in the chamber, and safety on. 
would be at the range by 07:30 and be gone by 09:00, before it really got hot.

Other range dividends soon accrued. Computers, fuel, and vehicles were in short supply. Support units that controlled those commodities soon began supplying us with these items in gratitude for providing them with an alternative to the Udairi range. Signal companies gave us outdated, unwanted, and unclassified computers that helped us expedite electronic medical record entries. Fuel distribution units gave us fuel exemption cards. Although vehicles for unit use were constantly being cut back, we regularly had several vehicles made available to us for a few days "off the books" between official unit assignments.

I now realized how black market economies spontaneously emerge in war zones. Some of my unit members began to complain about letting other units use our range if they had nothing to offer us in return, but I could not subscribe to that philosophy. One such complaint could shut us down and land me in deep trouble.

Range business was booming and yielded even more unexpected benefits. We had 2 ambulances to transport patients to downtown Kuwait City hospitals. At one point when both were in the repair shop, a private contracting company loaned us one of their ambulances for 2 weeks in gratitude for letting their security guards shoot at our range.

My replacement, an active duty Navy commanding officer, wanted no part of operating a pistol and rifle range, noting that was not part of the unit's mission. Maybe not, but successfully carrying out my medical mission would have been much more difficult had I not ventured outside the strict boundaries of my assignment and responsibility.

Expeditionary Medical Facility Dallas may be the only medical unit ever to have actively run a joint service shooting range in a forward combat zone. Without the perception of being pathetic, I doubt that this academic neurologist, who has never owned a gun, would have been permitted to operate such a facility that trained thousands of soldiers, sailors, and airmen.

Sometimes doctors can turn an adverse environment and bureaucratic rules to their advantage to enhance the efficiency and effectiveness of health care delivery. Although our mission was to conserve the fighting force and to treat those injured in war, I was more than willing to take advantage of the perception of being pathetic and turn that weakness into an asset that complemented and supported our medical mission. 


\title{
Neurology
}

\author{
Doctors without weapons: "You people are pathetic" \\ Jack E. Riggs \\ Neurology 2017;89; $151-\mathrm{e} 153$ \\ DOI 10.1212/WNL.0000000000004410
}

This information is current as of September 25, 2017

$\begin{array}{ll}\begin{array}{l}\text { Updated Information \& } \\ \text { Services }\end{array} & \begin{array}{l}\text { including high resolution figures, can be found at: } \\ \text { http://n.neurology.org/content/89/13/e151.full }\end{array} \\ \text { Subspecialty Collections } & \text { This article, along with others on similar topics, appears in the } \\ \text { following collection(s): } \\ \text { All Clinical Neurology } \\ \text { http://n.neurology.org/cgi/collection/all_clinical_neurology } \\ \text { All Ethics in Neurology/Legal issues } \\ \text { http://n.neurology.org/cgi/collection/all_ethics_in_neurology_legal_iss } \\ \text { ues } \\ \text { All Trauma } \\ \text { http://n.neurology.org/cgi/collection/all_trauma } \\ \\ \text { Information about reproducing this article in parts (figures,tables) or in } \\ \text { its entirety can be found online at: } \\ \text { http://www.neurology.org/about/about_the_journal\#permissions } \\ \text { Information about ordering reprints can be found online: } \\ \text { hermissions \& Licensing } \\ \text { http://n.neurology.org/subscribers/advertise }\end{array}$

Neurology ${ }^{\circledR}$ is the official journal of the American Academy of Neurology. Published continuously since 1951, it is now a weekly with 48 issues per year. Copyright (O 2017 American Academy of Neurology. All rights reserved. Print ISSN: 0028-3878. Online ISSN: 1526-632X.

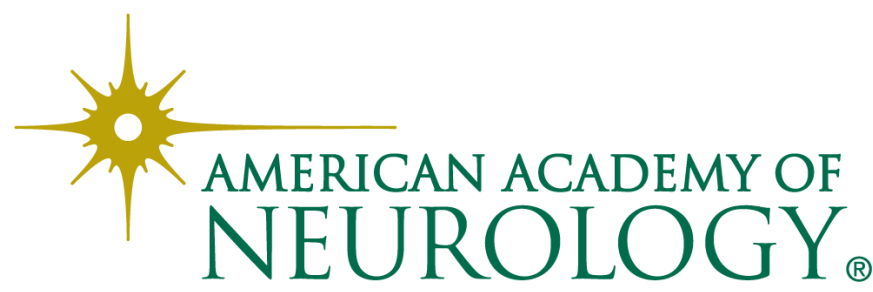

